\title{
ASSESSMENT OF SAFETY CULTURE BY SURGICAL UNIT NURSING TEAMS $^{1}$
}

\author{
Monique Mendes Marinho², Vera Radünz $z^{3,}$ Sayonara de Fátima Faria Barbosa ${ }^{4}$
}

\footnotetext{
${ }^{1}$ Partial result of the thesis - Nursing care and the patient safety culture: an assessment study at surgical inpatient units, presented to the Graduate Nursing Program (PEN) at Universidade Federal de Santa Catarina (UFSC), in 2012.

${ }^{2}$ Doctoral Student in PEN/UFSC. Nurse, UFSC University Hospital. Florianópolis, Santa Catarina, Brazil. E-mail: moniquemarinho@yahoo.com.br

${ }^{3}$ Ph.D. in Nursing. Faculty, Nursing Department and PEN/UFSC. Florianópolis, Santa Catarina, Brazil. E-mail: radunz@ccs. ufsc.br

${ }^{4}$ Ph.D. in Nursing. Faculty, Nursing Department and PEN/UFSC. Florianópolis, Santa Catarina, Brazil. E-mail: sayonara@ccs. ufsc.br
}

\begin{abstract}
The objective was to evaluate the patient safety culture from the perspective of the nursing teams at two surgical inpatient units of a university hospital, using the Safety Attitudes Questionnaire. Cross-sectional survey with quantitative approach, conducted at the two surgical inpatient units of the university hospital in Florianópolis, SC, Brazil. The Safety Attitudes Questionnaire was applied to 46 nursing professionals. Data analysis used descriptive and inferential statistics. The results show that all dimensions measured values scored lower than the minimum positive safety culture. The lower scores were found in the dimensions "perceptions of management" and "working conditions". Concerning the age of the professionals, young professionals stood out with higher scores. As for the professional categories, the higher scores were related to nursing assistants. The evaluation of the safety culture in the units studied demonstrates weakness in the six dimensions assessed.
\end{abstract}

DESCRIPTORS: Safety. Nursing. Nursing care. Culture. Inpatient care units.

\section{AVALIAÇÃO DA CULTURA DE SEGURANÇA PELAS EQUIPES DE ENFERMAGEM DE UNIDADES CIRÚRGICAS}

\begin{abstract}
RESUMO: O estudo teve como objetivo avaliar a cultura de segurança do paciente, sob a ótica dos profissionais de enfermagem de duas unidades de internação cirúrgica, de um hospital universitário, a partir do Safety Attitudes Questionnaire (SAQ). Trata-se de uma pesquisa quantitativa, do tipo survey transversal, realizado nas duas unidades de internação cirúrgica do hospital universitário em Florianópolis, SC, Brasil. Aplicou-se o SAQ a 46 profissionais de enfermagem. Para análise dos dados, utilizou-se a estatística descritiva e inferencial. Os resultados mostravam que todas as dimensões avaliadas obtiveram valores inferiores ao mínimo positivo para a cultura de segurança, com menores escores nas dimensões "percepções da gestão" e "condições de trabalho". Em relação à idade do profissional, os mais jovens destacaram-se com maiores escores. Quanto às categorias profissionais, os escores superiores relacionaram-se aos auxiliares de enfermagem. Assim, a avaliação da cultura de segurança, nas unidades do estudo, demonstra fragilidade nas seis dimensões consideradas.

DESCRITORES: Segurança. Enfermagem. Cuidados de enfermagem. Cultura. Unidades de internação.
\end{abstract}

\section{EVALUACIÓN DE LA CULTURA DE SEGURIDAD POR EL EQUIPO DE ENFERMERÍA DE UNIDADES QUIRÚRGICAS}

\begin{abstract}
RESUMEN: Evaluar la cultura de la seguridad del paciente desde la perspectiva de las enfermeras de las unidades de hospitalización quirúrgica de un hospital universitario del Cuestionario de Actitudes de Seguridad (SAQ). Estudio con enfoque cuantitativo, de tipo encuesta transversal, realizada en dos unidades quirúrgicas de un hospital universitario de Florianópolis, SC, Brazil. Se aplicó el SAQ a 46 profesionales de enfermería. El análisis de datos utilizado la estadística descriptiva e inferencial. Los resultados muestran que todas las dimensiones de los valores medidos fueron inferiores a la cultura de seguridad mínima positiva, las dimensiones con puntuaciones más bajas fueron: "la percepción de la gestión" y las "condiciones laborales". En cuanto a la edad de los profesionales, los más jóvenes se destacaron por obtener las puntuaciones más altas. En cuanto a las categorías profesionales, los puntajes más altos se relacionan con los auxiliares de enfermería. La evaluación de la cultura de la seguridad en las unidades de estudio demuestra debilidad en seis dimensiones evaluadas.
\end{abstract}

DESCRIPTORES: Seguridad. Enfermería. Atención de enfermería. Cultura. Unidades de internación. 


\section{INTRODUCTION}

Healthcare delivery is considered a global challenge, due to the large number of problems related to patient safety. Physicians, nurses or other professionals rarely violate the traditional medical oath, based on Hippocrates, which states "never do harm to anyone", on purpose, but the truth is that the patients are affected daily, all over the world, in the course of healthcare. ${ }^{1}$

Healthcare is frequently delivered in an environment under pressure of results, which changes rapidly due to a large technological apparatus and health professionals' many individual decisions and judgments. Under such circumstances, errors may happen. ${ }^{2}$

Greater concerns with patient safety emerged more than 30 years ago, based on studies in developed countries with highly negative results, arousing questions on the quality of healthcare delivery all over the world. These studies showed that adverse events caused care-related injuries, which led to temporary or permanent disability, to extended hospitalizations or to patient death. These events would be avoidable in around 30 to $60 \%$ of the situations described. ${ }^{3}$

The publication that is considered a global alert to the patient safety problem was the book To err is human: building a safer health system, which the North American Institute of Medicine presented in 1999. It was demonstrated that between 44,000 and 98,000 Americans died every year as a result of healthcare errors, which should be avoided. ${ }^{4}$

Safety is a big problem. Therefore, the main factors causing errors should be understood, which are essential to conceive effective and efficient solutions for the different contexts and environments and to build safer health systems. ${ }^{5}$

The studies that demonstrate the severe patient safety problem highlight the need for health organizations to develop a safety culture, allowing the workforce and the processes to be focused on the improvement of trust as well as the safety of patient care..$^{3-4}$

As the World Health Organization recommended attention to the theme, in Brazil, the Ministry of Health established the National Patient Safety Program (NPSP), on April $1^{\text {st }} 2013$. The objective of the program is to contribute to the qualification of healthcare in all health establishments across the national territory. ${ }^{6}$

The Brazilian initiative indicates the State's concern with the promotion of patient safety. It is believed that, to achieve care quality and guarantee better results, changes in the healthcare culture are fundamental, in which the errors should not be perceived as the result of incompetent human action, but mainly as opportunities to improve the system, promoting a safety culture. ${ }^{7}$

The term safety culture was introduced after the nuclear accident in Chernobyl in $1986,{ }^{8}$ defined as the support and form of attitudes and practices of the organizational members towards the detection and learning from errors. ${ }^{9}$

The safety culture is increasingly acknowledged as an important strategy to improve the generalized deficit in patient safety, defined and measured in different ways, and one may say that, at bottom, the culture is "the way we do things around here", in which "here" refers to the work unit. ${ }^{10}$

The punitive culture that has historically ruled in health institutions creates more damage than benefits. In addition, in the belief that there will always exist errors, the most logical and necessary action for the organization should be focused on the creation of an educative instead of punitive educational culture, starting from the reporting and analysis of errors and adverse events. ${ }^{11}$ Thus, the health organizations need to make efforts to overcome the traditional culture of blame and punishment and encourage the safety culture, based on the culture of reporting and learning. ${ }^{12}$

The safety culture can be subjectively measured through the use of safety climate questionnaires, which are aimed at discovering the attitudes of the workforce and its perceptions in a given period. ${ }^{13}$ This practice is considered an important step to improve the safety. ${ }^{14}$

In this study, the Safety Attitudes Questionnaire (SAQ), a psychometric research instrument that is considered the best tool for this measure, being formally validated and used all over the world. ${ }^{15}$ This questionnaire has been validated and adapted to the Brazilian reality. ${ }^{16}$

This study is mainly justified because, by assessing the safety culture of a hospital, the 
dimensions in which improvements are needed can be identified, permitting the planning and implementation of appropriate interventions that promote patient safety. ${ }^{14}$

Hence, the objective in this research was to assess the patient safety culture from the perspective of the nursing at the surgical inpatient units of a university hospital, based on the SAQ.

\section{METHOD}

Quantitative and cross-sectional survey, undertaken at two surgical inpatient units of the university hospital in Florianópolis-SC, Brazil. The study population consisted of the nursing team members: baccalaureate nurses, nursing technicians and auxiliary nurses, who work at the surgical inpatient units under analysis, totaling 46 professionals. A non-probabilistic intentional sample was used.

The inclusion criterion to select the participants was having worked at least four weeks at the places of study. Long periods of absence during the data collection period were considered as an exclusion criterion.

To develop the study, the ethical premises in National Health Council Resolution 196/96 ${ }^{17}$ were complied with. Approval was obtained from the Research Ethics Commission (CEP) at Federal University of Santa Catarina, registered under certificate 1076/10.

The data collection instrument was the SAQ - operating room version, translated to Portuguese, whose application was authorized by the authors, entitled Questionário de Atitudes de Segurança. The SAQ assesses the professional's relevant attitudes for patient safety ${ }^{14}$ and consists of demographic data, 64 items formulated as sentences that should be answered on a five-point Likert scale, one section to assess the quality of the level of collaboration and communication with the other professionals on the team and one discursive question about three recommendations to improve patient safety at the unit, which were grouped by similarity, after which categories were established. ${ }^{18}$

For the assessment, only the 30 items that are part of the safety dimensions were considered, which are: teamwork climate; satisfaction at work; management perceptions; safety cli- mate; working conditions; and acknowledgement of stress, as proposed by the authors of the questionnaire. ${ }^{18}$

To test the understanding of the translated instrument, a pretest of the SAQ was applied to five nursing professionals who had worked at the units studied, which permitted making adjustments to the questionnaire. During the data collection, the SAQ was being validated for the Brazilian reality, making it impossible to use the validated instrument. ${ }^{16}$ Therefore, the original instrument was translated, followed by a pretest.

The data were collected between April and July 2011. The professionals were invited to participate in the research after the study objective and the research dynamics had been clarified and the Terms of Free and Informed Consent had been completed. Each participant received an envelope with the questionnaire which, after completion, was deposited in a sealed box available at the unit, thus guaranteeing secrecy to the participant. After collecting the box, the envelopes were passed to a typist, who included the instrument data in an electronic worksheet for calculation, after which the envelopes were again sealed and returned to the researcher for filing.

The data were organized in the software Microsoft Office Excel 2003® and exported to the online computer tool SestatNet - Environment for Statistics Teaching and Learning on the Web. ${ }^{19}$

The collected data were analyzed through descriptive statistics (absolute and relative frequencies, means, standard deviations); for inferential statistics, tests were developed between qualitative and quantitative variables. Due to the non-normal distribution of the data, KruskalWallis' ANOVA (analysis of variance) test was applied. For this study, significance was set as $p$ $\leq 0.05$ for a $95 \%$ confidence interval.

The SAQ items were assessed based on patient safety culture scores in each dimension. Thus, the score was considered positive when equal to or higher than 75, on a scale from 0 to 100 , converting the five points of the Likert scale as follows: the item marked as 1- I completely disagree, corresponding to score 0 ; 2 - I partially disagree, score 25; 3- neutral, score 50; 4- I partially agree, score 75 and 5 - I completely agree, score 100 . Hence, the options "I partially agree" and/or "I completely 
agree" were considered positive answers, scored as four and five, respectively, except for two questions with a reverse score.

\section{RESULTS}

In this study, 46 out of the 53 nursing professionals who work at the two surgical inpatient services of the university hospital in FlorianópolisSC, Brazil and complied with the inclusion criteria completed the SAQ. Thus, the response rate corresponds to $86.7 \%$. These two hospitalization units are presented as unit $\mathrm{A}$ and unit $\mathrm{B}$, with response rates of $96.7 \%$ and $72.7 \%$, respectively.

The study participants' sociodemographic characteristics are displayed in Table 1 . The analysis of these characteristics revealed that most professionals were nursing technicians (52.3\%), followed by baccalaureate nurses $(31.8 \%)$ and auxiliary nurses $(15.9 \%)$. Women were predominant, totaling $83.7 \%$. The professionals' age ranged between 25 and 66 years and was organized in four age groups. As regards the length of these professionals' experience at the surgical units, the majority has worked in the area for more than ten years $(44.2 \%)$.

All participants work a mean 30 hours per week, divided in six-hour (morning and afternoon) and/or 12-hour shifts (day and night).

Table 1 - Sociodemographic characteristics of nursing professionals at the surgical inpatient units of the university hospital in FlorianópolisSC, Brazil

\begin{tabular}{lc}
\hline Sociodemographic characteristics & $\mathbf{n}(\mathbf{\%})$ \\
\hline Professional category $(\mathbf{n}=\mathbf{4 4})$ & \\
Baccalaureate nurse & $14(31.8)$ \\
Nursing technician & $23(52.3)$ \\
Auxiliary nurse & $7(15.9)$ \\
Not answered & 2 \\
Sex $(\mathbf{n}=\mathbf{4 3})$ & \\
Female & $36(83.7)$ \\
Male & $7(16.3)$ \\
Not answered & 3 \\
Age $(\mathbf{n}=\mathbf{3 9})$ & $8(20.5)$ \\
20-30 &
\end{tabular}

\begin{tabular}{lc}
$31-40$ & $12(30.7)$ \\
$41-50$ & $10(25.6)$ \\
51 or older & $9(23.1)$ \\
Not answered & 7 \\
Length of professional experience at & \\
surgical units $(\mathbf{n}=\mathbf{4 2})$ & $12(28.6)$ \\
0 - 05 years & $14(33.3)$ \\
06 - 10 years & $4(9.5)$ \\
11 - 15 years & $7(16.7)$ \\
$16-20$ years & $5(11.9)$ \\
$>20$ years & 4 \\
Not answered & \\
\hline
\end{tabular}

The following figure (Figure 1) shows the scores in each of the six dimensions of the safety culture, according to the SAQ. The score found for each unit and the general score are highlighted, when units A and B are analyzed on the whole.

The units in this study significantly emphasized the highest and favorable scores in the dimension "satisfaction at work" (71.3), in which the pride to work at the institution and contentment stand out. In this dimension, the item with the highest score (92.9) is related to the following assertion: I like my work.

The nursing professionals granted the items in the dimension "acknowledgement of stress" the second highest score in the study (65). In this dimension, however, unit A obtained the lowest score when compared to unit $B$, with 50.5 against 57.2. Concerning the other dimensions, unit $\mathrm{A}$ always obtained the highest score when compared to the other unit.

The research participants scored the dimensions "management perceptions" (39) and "working conditions" (40) significantly more negatively. At unit B, however, the even lower scores for "working conditions" stand out (32). The item that stood out negatively in this dimension was: Trainees in my area are adequately supervised, with score 21.7.

The average scores for the dimensions "safety climate" (50.3) and "teamwork climate" (52.3) are close. In both dimensions, however, unit B obtained slightly lower averages (48.5 and 50.3) when compared to unit A. 


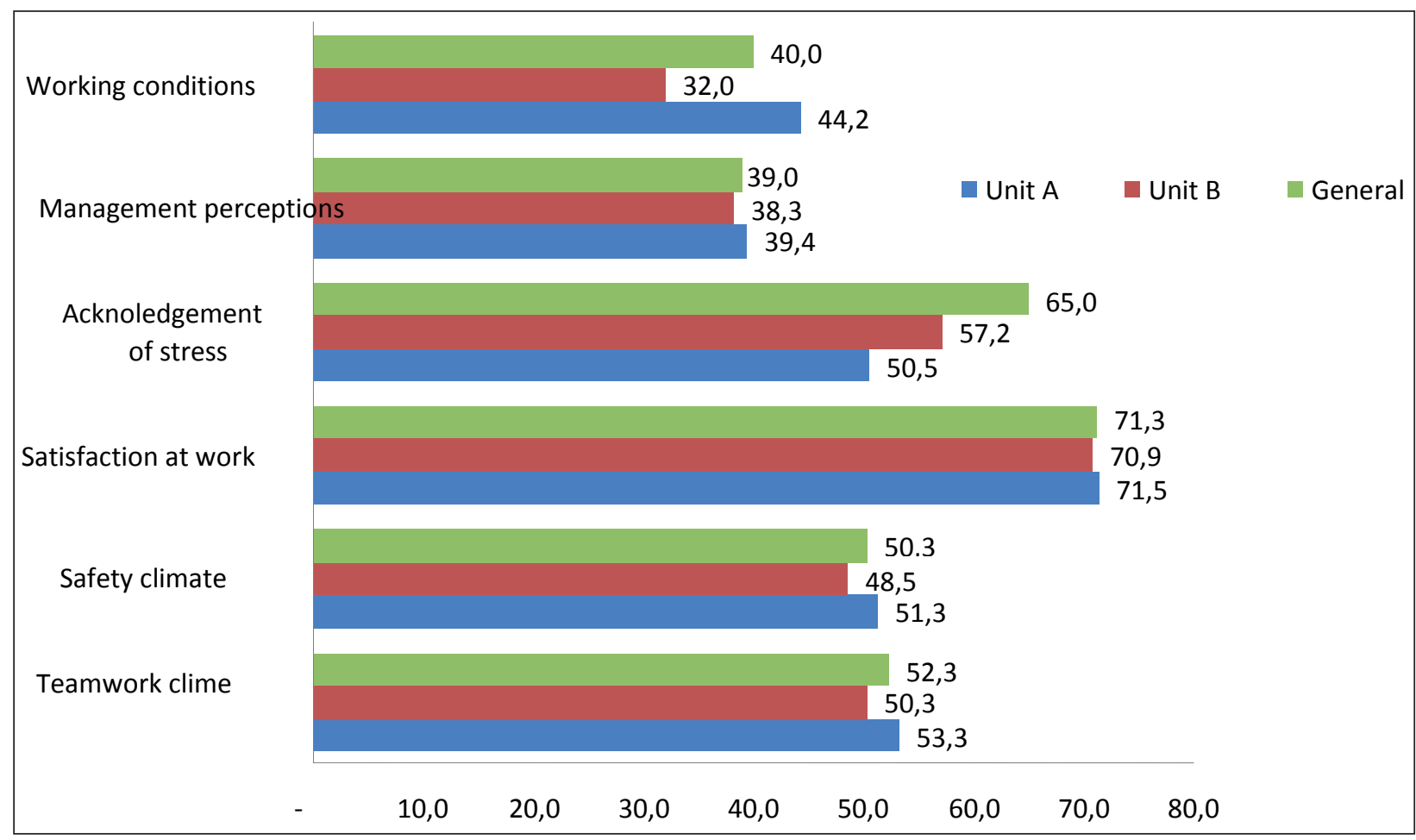

Figure 1 - Safety culture dimension scores, based on the assessment of nursing professionals working at the surgical inpatient units under study. Florianópolis-SC, 2011

To analyze the data in this study, the ANOVA test was also applied to assess significant differences between the safety culture dimensions and the nursing professionals' age (Table 2). In total, seven professionals did not answer the question about their age, so that the data from 39 professionals were used for this analysis.

Although the mean scores demonstrate differences in the age ranges assessed, only the "working conditions" dimension was statistically significant, with a p-value of 0.041 .

In five out of six dimensions assessed, lower means were identified in the age range from 31 to 40 years. Younger professionals however, with ages between 20 and 30 years, reached higher averages in most dimensions. 
Table 2 - Patient safety culture according to professional's age and ANOVA test result. FlorianópolisSC, 2011

\begin{tabular}{|c|c|c|c|c|c|c|}
\hline Dimension & Category (years) & $\mathbf{n}$ & Mean score & Standard deviation & $\mathbf{H}$ & $p_{\text {value }}$ \\
\hline \multirow[t]{4}{*}{ Teamwork climate } & $20-30$ & 8 & 57.81 & 13.98 & 2.62 & 0.62 \\
\hline & $31-40$ & 12 & 48.95 & 13.77 & & \\
\hline & $41-50$ & 10 & 55.00 & 14.40 & & \\
\hline & 51 or older & 9 & 51.38 & 12.67 & & \\
\hline \multirow[t]{4}{*}{ Safety climate } & $20-30$ & 8 & 48.80 & 13.05 & 2.29 & 0.68 \\
\hline & $31-40$ & 12 & 44.94 & 14.40 & & \\
\hline & $41-50$ & 10 & 49.46 & 8.91 & & \\
\hline & 51 or older & 9 & 52.11 & 11.93 & & \\
\hline \multirow[t]{4}{*}{ Satisfaction at work } & $20-30$ & 8 & 79.38 & 11.47 & 5.02 & 0.28 \\
\hline & $31-40$ & 12 & 67.50 & 7.83 & & \\
\hline & $41-50$ & 10 & 70.00 & 20.13 & & \\
\hline & 51 or older & 9 & 71.66 & 16.00 & & \\
\hline \multirow[t]{4}{*}{ Acknowledgement of stress } & $20-30$ & 8 & 78.90 & 19.46 & 5.75 & 0.21 \\
\hline & $31-40$ & 12 & 63.54 & 18.23 & & \\
\hline & $41-50$ & 10 & 61.25 & 20.36 & & \\
\hline & 51 or older & 9 & 61.80 & 12.67 & & \\
\hline \multirow[t]{4}{*}{ Management perceptions } & $20-30$ & 8 & 38.28 & 16.84 & 4.09 & 0.39 \\
\hline & $31-40$ & 12 & 33.33 & 12.30 & & \\
\hline & $41-50$ & 10 & 40.62 & 12.58 & & \\
\hline & 51 or older & 9 & 45.13 & 11.17 & & \\
\hline \multirow[t]{4}{*}{ Working conditions } & $20-30$ & 8 & 50.00 & 11.08 & 9.93 & 0.04 \\
\hline & $31-40$ & 12 & 32.81 & 12.24 & & \\
\hline & $41-50$ & 10 & 38.12 & 14.86 & & \\
\hline & 51 or older & 9 & 47.45 & 13.84 & & \\
\hline
\end{tabular}

The ANOVA test result for the different professional categories showed no significance (Table $3)$. According to the analysis of means, however, in most dimensions, lower scores were observed for baccalaureate nurses and higher scores in the auxiliary nurses' assessment. In this analysis, 44 professionals were considered, as two did not answer what professional category they belonged to.

Table 3 - Patient safety culture according to professional category and ANOVA test result. Florianópolis-SC, 2011

\begin{tabular}{clccccc}
\hline Dimension & \multicolumn{1}{c}{$\begin{array}{c}\text { Variable/ } \\
\text { category }\end{array}$} & $\mathbf{n}$ & Mean score & $\begin{array}{c}\text { Standard } \\
\text { deviation }\end{array}$ & H & $\mathbf{p}_{\text {value }}$ \\
\hline \multirow{3}{*}{ Teamwork climate } & Bacc. nurse & 14 & 48.21 & 17.11 & & \\
& Nursing technician & 23 & 56.34 & 11.97 & 5.52 & 0.13 \\
& Aux. nurse & 7 & 53.57 & 11.88 & & \\
& Bacc. nurse & 14 & 45.91 & 14.06 & & \\
Safety climate & Nursing technician & 23 & 50.75 & 11.95 & 3.17 & 0.36 \\
& Aux. nurse & 7 & 52.21 & 12.77 & & \\
Satisfaction at work & Bacc. nurse & 14 & 68.57 & 10.08 & & \\
& Nursing technician & 23 & 72.60 & 15.21 & 5.68 & 0.12 \\
& Aux. nurse & 7 & 76.42 & 16.25 & & \\
Acknowledgement of stress & Bacc. nurse & 14 & 69.19 & 13.53 & & \\
& Nursing technician & 23 & 63.85 & 22.84 & 4.41 & 0.21 \\
& Aux. nurse & 7 & 55.35 & 12.19 & &
\end{tabular}




\begin{tabular}{clccccc}
\hline & Bacc. nurse & 14 & 37.50 & 13.64 & \\
Management perceptions & Nursing technician & 23 & 39.40 & 12.41 & 0.78 & 0.85 \\
& Aux. nurse & 7 & 42.85 & 14.17 & \\
& Bacc. nurse & 14 & 37.94 & 14.80 & 3.43 & 0.32 \\
& Nursing technician & 23 & 41.12 & 14.06 & 3.70 & \\
\hline
\end{tabular}

In the analysis of the level of collaboration and communication, the percentage of positive answers was found for each professional group. The result shows low percentages of positive answers, which compromise the relation and teamwork (Table 4). The most negative percentage is related to the medical team, which includes both the head physician and staff and resident physicians. Similar percentages of positive answers were also identified for the level of communication and collaboration with physiotherapists.

Some differences in the assessments of this part were identified between units $\mathrm{A}$ and $\mathrm{B}$. The largest difference is related to the assessment by the bookkeeper, as unit A obtained an evaluation with $20 \%$ of positive answers, against $73.3 \%$ at unit B.

Table 4 - Assessment of the percentage of positive answers to the level of collaboration and communication between nursing and other professionals. Florianópolis-SC, 2011

\begin{tabular}{lrc}
\hline $\begin{array}{l}\text { Level of collaboration and } \\
\text { communication }\end{array}$ & Unit A (\%) & Unit B (\%) \\
\hline Head physician & 5.0 & 16.6 \\
Head nurse & 10.7 & 37.5 \\
Shift nurse & 48.1 & 53.3 \\
Staff physicians & 16.0 & 0 \\
Residents & 7.1 & 26.6 \\
Physiotherapist & 3.7 & 12.5 \\
Bookkeeper & 20.0 & 73.3 \\
\hline
\end{tabular}

The SAQ also contains a discursive question to identify the study participants' recommendations to improve the patient safety at their unit.

The professionals' recommendations resulted in 17 categories and are presented according to the highest frequencies in the professionals' answers: 1. Participation in more training, qualification and recycling; 2 . Use of appropriate material and equipment; 3. Hiring of more staff; 4. Attention and responsibility; 5. Adequate com- munication among professionals; 6 . More careful medical assessment of patients; 7. Expansion and structuring of physical area; 8. Collaboration among team members; 9 . Training and monitoring of new staff; 10 . Orientation to patients and companions; 11. Adaptation of cleaning service; 12. Professional motivation; 13. Penalty of bad professionals; 14. Valuation of Nursing; 15. Appropriate management; 16 . Prohibition to transfer professional activities to companions; 17 . Abstention from long and uninterrupted workdays.

\section{DISCUSSION}

The study results indicate that relevant aspects of the patient safety culture at these hospitalization units need to be addressed. The assessment of the mean scores demonstrates that all of the dimensions assessed obtained scores inferior to 75 , considered the positive minimum for the safety culture in this study.

The study population mostly includes female professionals, confirming the characteristic of the profession. ${ }^{20}$ The nursing professionals who participated in the study revealed professional experience in the surgical area, which according to another study translates appropriate and useful knowledge to assess the safety culture. ${ }^{20}$

These nursing professionals identified the weakness of the hospital management. This critical perception attracts attention to the need for the management to support patient safety, requiring actions that favor the quality of care.

The experience of other authors reveals that, when the management of a health institution commits to safety, it provides appropriate support and resources, engaging in the improvement of the operational efforts, such as: equipment, procedures, selection, training and work hours, when are routinely assessed and, if necessary, modified to improve the patient safety. ${ }^{21}$

In the assessment of the working conditions, the need for qualification was observed, mainly 
with regard to personnel and professional training. Many professionals are predisposed to errors due to the excessive workload, with many of them working when they are totally exhausted. In such conditions, they tend to work carelessly and end up committing errors. ${ }^{22}$

As regards the professionals' training, the conception is highlighted that effective training is considered one of the key elements for a highquality health institution. A knowledge base is essential for improvements in patient safety, demanding the creation of a learning system that can guarantee qualified health professionals who are aware of the limits of their competency. ${ }^{23}$

Nevertheless, satisfaction at work was a strength evidenced in the group under analysis. In that sense, it is important to highlight that the professionals are satisfied to act at the institution in order to turn the work environment into a safer place. For some authors, ${ }^{24-25}$ improving the satisfaction at work can lead to an increase in the job performance and, consequently, enhance the quality of patient safety.

As to the age range, no significant difference was found among the dimensions teamwork climate, safety climate, satisfaction at work, acknowledgement of stress and management perceptions in relation to age, demonstrating that, independently of the professional's age range, the safety culture is perceived homogeneously.

In the dimension working conditions, a significant difference was observed with regard to the participants' age, in which the group from 20 to 30 years reached the highest scores and the group from 31 to 40 the lowest. The results of other studies demonstrate some differences: in general younger nursing professionals are less positive in their assessments of the safety culture. ${ }^{20,26-27}$

Although the different categories of nursing professionals share the same space and time in their workday, in this study, the auxiliary nurses obtained higher scores. These professionals have been working at the institution longer and this professional category has not been hired in the most recent selection processes for legal reasons. Due to their longer work experience at the institution, they possibly perceive growth and improvement in recent years in comparison with earlier work conditions.
The different assessments of the quality of collaboration and communication among the units can be justified by the fact that only unit $B$ has a staff member working as a bookkeeper, while unit A is sometimes able to hire a grantee to perform the same function, through temporary contracts of one year at most. These assessments, however, are not considered positive, characterizing a weakness in the collaboration and communication process. Except for the bookkeeper's assessment at unit B, the highest percentage of positive answers in this assessment corresponds to the nursing team, mainly the shift nurse, with $48.1 \%$ and $53.3 \%$, respectively.

The low score attributed to the quality of the collaboration and communication among the professionals in this study may entail implications for patient safety, as the communication and collaboration problems among the health professionals can represent a potential source of errors, entailing ruptures in the continuity of the services provided, as well as inappropriate or hardly effective treatments and procedures, with immediate and potentially negative effects for the patients. ${ }^{28-29}$

The participants' recommendations to improve the patient safety are similar to the low scores found in the dimensions assessed, that is, these professionals suggest that the main actions needed are: participation in more training, qualification and recycling; Use of appropriate material and equipment; hiring of more staff. These actions are related to the working conditions and the activities of hospital managements, which the nursing staff assesses negatively.

Hence, to overcome problems, the existence of weaknesses needs to be acknowledged in all healthcare activities, which can compromise the patient safety. In addition, the key to reduce the risk is to create an environment in which the culture of blame is replaced by the culture of surveillance and cooperation. ${ }^{30}$

\section{FINAL CONSIDERATIONS}

The assessment of the safety culture at the surgical inpatient units in this study demonstrates weaknesses in the six dimensions assessed, mainly regarding the hospital management work and the working conditions.

Based on this study, the safety culture at these services needs improvements. This change 
demands efforts and the involvement of the entire institution, mainly the managers, with a view to encouraging the reporting of errors and strengthening the culture of non-punishment, offering a work environment in which patient safety is valued.

Another important challenge is related to communication and collaboration among the professionals. The baccalaureate nurses, nursing technicians and auxiliary nurses who participated in this study consider the communication and teamwork deficient, even with the shift nurse. These results reflect little mutual interaction among the professionals, without support or information exchange, not even when everyone is engaged and works for the same objective: the patient. In that sense, the commitment and individual efforts of each professional is highlighted to improve the safety culture and, consequently, communication and collaboration among the team members.

Although the study only involved nursing professionals, the large majority of the nursing staff participated, corresponding to the largest group of workers active in patient care. Despite this limitation in terms of professional category, these study results can help to plan and develop patient safety strategies.

As this research was concentrated in two inpatient units, it could be replicated in other hospital services to identify the weaknesses and potentials of each work area, aiming for a planned changed based on the assessment of the professionals who work in healthcare each day and, at the same time, aiming to sensitize them to the theme of patients' safety and needs.

\section{REFERENCES}

1. Organización Mundial de la Salud(OMS). Preámbulo a las soluciones para la seguridad del paciente. Geneva (CH): OMS, 2007.

2. World Health Organization. World Alliance for Patient Safety: forward programme 2005. World Health Organization, Geneva. 2004 [acess 2011 Dez 17]. Available in: http://www.who.int/ patientsafety/en/brochure_final.pdf

3. Zambon LS. Riscos e eventos adversos: uma realidade alarmante. Medicina Net. 2008 [acesso 2013 Jun 01]. Disponível em: http:/ / 186.202.143.44/ conteudos/gerenciamento/901/introducao__ primum_non_nocere.htm

4. Institute of Medicine. To err is human: building a safer health system. Washington (US): National
Academy Press, 2000.

5. World Health Organization. Patient safety: global priorities for research in patient safety. Geneva $(\mathrm{CH})$ : World Health Organization; 2008.

6. Ministério da Saúde (BR) [online]. Portaria n. 529 de 1 de abril de 2013. Institui o Programa Nacional de Segurança do Paciente (PNSP) [acesso 2013 Mai 24]. Brasília (DF): MS; 2013. Disponível: http:// bvsms.saude.gov.br/bvs/saudelegis/gm/2013/ prt0529_01_04_2013.html

7. Institute of Medicine. Crossing the quality chasm: a new health system for the $21^{\text {st }}$ century. Whashington (US): National Academy Press; 2001.

8. Cooper MD. Towards a model of safety culture. safety Science. 2000; (36):111-36.

9. Health and Safety Commission. Organizing for Safety: Third Report of the Human Factors Study Group of ACSNI. London (UK): HSE Books; 1993.

10. Pronovost P, Sexton B. Assessing safety culture: guidelines and recommendations. Qual Saf Health Care. 2005 Aug; 14(4):231-3.

11. Franco A. La seguridad clínica de los pacientes: entendiendo el problema. Colombia Médica. 2005 Abr; 36(2):130-3.

12. Neto AQ. Segurança dos pacientes, profissionais e organizações: um novo padrão de assistência à saúde. RAS. 2006 Out; 8(33):153-8.

13. Health and Safety Executive. A review of safety culture and safety climate literature for the development of the safety culture inspection toolkit. London (UK): Human Engineering Bristol; 2005.

14. Sexton JB, Thomas EJ. The safety attitudes questionnaire $(S A Q)$ : guidelines for administration. Texas (US): University of Texas, Center of Excellence for Patient Safety Research and Practice; 2003.

15. Sexton JB, Paine LA, Manfuso J, Holzmueller CG, Martinez EA, Moore D, et al. A check-up for safety culture in my patient care area. Jt Comm J Qual Patient Saf. 2007 Nov; 33(11):699-703.

16. Carvalho REFL, Cassiani SHB. Questionário atitudes de segurança: adaptação transcultural do Safety Attitudes Questionnaire - Short Form 2006 para o Brasil. Rev Latino-Am Enferm. 2012; 20(3):575-82.

17. Ministério da Saúde (BR). Conselho Nacional de Saúde, Comissão Nacional de Ética em Pesquisa. Resolução n. 196 de 10 de outubro de 1996: diretrizes e normas regulamentadoras de pesquisa envolvendo seres humanos. Brasília (DF): MS; 1996.

18. SextonJB,Helmreich RL, Neilands TB, RowanK, Vella $\mathrm{K}$, Boyden J, et al. The safety attitudes questionnaire: psychometric properties, benchmarking data, and emerging research. BMC Health Serv Res. 2006 Apr 3; 6:44.

19. SEstatNet - Sistema especialista para o ensino de estatística na web [acesso 2011 Dez 17]. Disponível em: http://www.sestat.net 
20. Fernandes AMML, Queirós PJP. Cultura de segurança do doente percepcionada por enfermeiros em hospitais distritais portugueses. Rev Enferm Referência. 2011 Jul; 3(4):37-48.

21. Wiegmann DA, Zhang H, Thaden $T$, Sharma G, Mitchell A. A synthesis of safety culture and safety climate research. University of Illinois at UrbanaChampaign. 2002. Prepared for Federal Aviation Adminstration: Techinal Report ARL-02-3/FAA-02-2.

22. Leape L. Errors in medicine. Clinica Chimica Acta. 2009 Jun; 404(1):2-5.

23. Commission on Patient Safety and Quality Assurance. Building a culture of patient safety: report of the Commission on Patient Safety and Quality Assurance. Department of Health and Children. Ireland (IR): Stationery Office; 2008.

24. Wisniewski AM, Erdley WS, Singh R, Servoss TJ, Naughton BJ, Singh G. Assessment of Safety Attitudes in a Skilled Nursing Facility. Geriatr Nurs. 2007 Mar-Apr; 28(2):126-36.

25. Zakari NMA. Attitude of academic ambulatory nurses toward patient safety culture in Saudi Arabia. Life Scienc J. 2011; 8(3):230-7.

26. Abdou HA, Saber KMM. A baseline assessment of patient safety culture among nurses at student university hospital. World J Med Sci. 2011; 6(1):7-26.

27. Holden LM; Watts DD, Walker PH. Patient safety climate in primary care: age matters. J Patient Saf. 2009 Mar; 5(1):23-8.

28. Santos MC, Grilo A, Andrade G, Guimarães T, Gomes A. Comunicação em saúde e a segurança do doente: problemas e desafios. Rev Port Saúde Pública. 2010; Vol Temat(10):47-57.

29. Abbas HA, Bassiuni NA, Baddar FM. Perception of front-line healthcare providers toward patient safety: a preliminary study in a university hospital in egypt. Topics Ad Pract Nursing Journal. 2008; 8(2):1-11.

30. Camerini FG, Silva LD. Segurança do paciente: análise do preparo de medicação intravenosa em hospital da rede sentinela. Texto Contexto Enferm. 2011 Jan-Mar; 20(1):41-49. 